
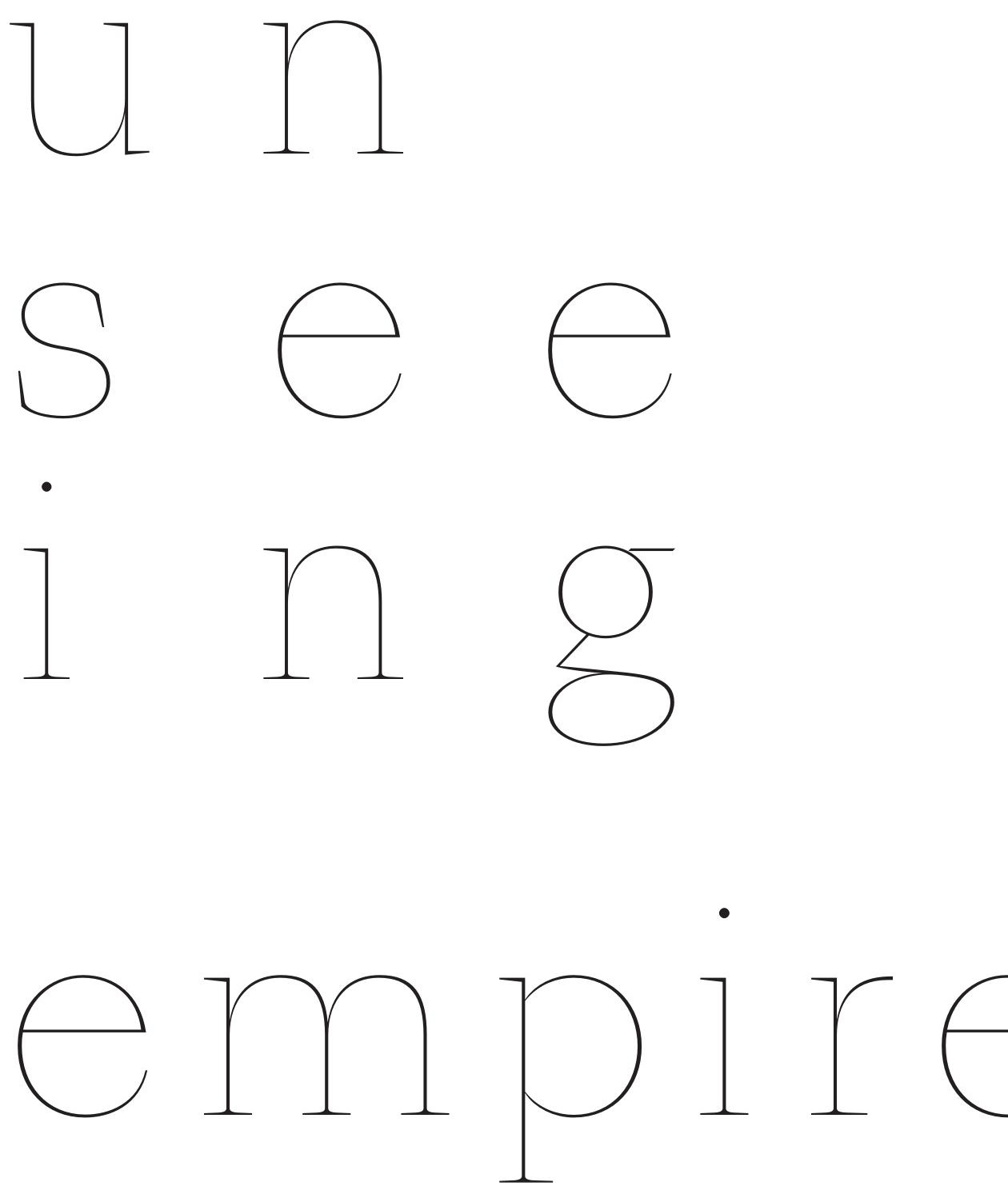

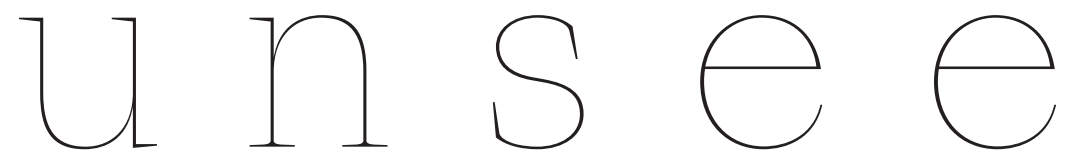

\section{PHOTOGRAPHY, REPRESENTATION,} SOUTH ASIAN AMERICA 

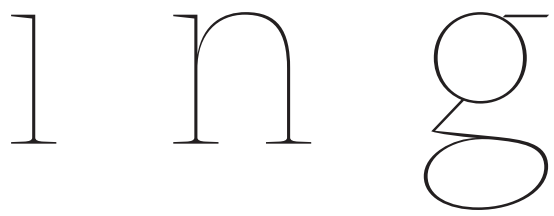

BAKIRATHI MANI
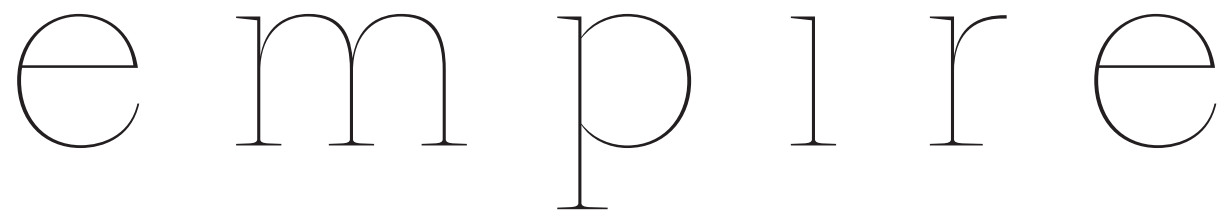
(C) 2020 Duke University Press

All rights reserved

Printed in the United States of America on acid-free paper $\infty$

Designed by Aimee C. Harrison

Typeset in SangBleu and Univers LT Std by Copperline Book Services

Library of Congress Cataloging-in-Publication Data

Names: Mani, Bakirathi, author.

Title: Unseeing empire : photography, representation,

South Asian America / Bakirathi Mani.

Other titles: Camera obscura book.

Description: Durham : Duke University Press, 2020.| Series: A camera obscura book | Includes bibliographical references and index.

Identifiers: LCCN 2020018442 (print)

LCCN 2020018443 (ebook)

ISBN 9781478009849 (hardcover)

ISBN 9781478010890 (paperback)

ISBN 9781478012436 (ebook)

Subjects: LCSH: South Asian Americans-Cultural assimilation-

United States. | South Asian Americans-Ethnic identity. | South

Asian diaspora.

Classification: LCC E184.s69 M365 2020 (print) |

LCC E184.s69 (ebook) | DDC 909/.04914-dc23

LC record available at https://lccn.loc.gov/2020018442

LC ebook record available at https://lccn.loc.gov/2020018443

Cover art: Seher Shah, The Expansion Complex II, 2009. Archival giclée print, $137 \times 81 \mathrm{~cm}$. Courtesy of the artist.

Duke University Press gratefully acknowledges the Hungerford Faculty Support Fund at Swarthmore College, which provided funds toward the publication of this book. 
FOR MARIO, AND FOR THE INFINITE LOVE WE SHARE WITH OUR SON, AMAR 